\title{
MODEL ON THE IMPROVEMENT OF INNOVATIVE BASED MARKETING PERSONNEL PERFORMANCE AT PT.BPR NUSAMBA CEPIRING
}

\author{
Tonny Frediyanto1*, Budhi Cahyono2*
}

* Affiliation:
${ }_{1,2}$ Master Program of
Management, Sultan
Agung Islamic University
Semarang
tonnyfrediyanto@ gmail.
com

* Affiliation:

${ }_{1,2}$ Master Program of Agung Islamic University tonnyfrediyanto@gmail.
This study aims to examine the effect of learning orientation on innovative performance and its impact on the Marketing personnel performance with internal audit supervision as moderation. The problem of research is how to improve the marketing personnel performance through learning orientation and innovative performance with internal audit supervision as moderation? The sample of this research is all marketing personnel who work in PT. BPR Nusamba Cepiring with a total of 101 respondents. Regression analysis is run with Statistical Package Social Science (SPSS) software to analyze the data. The result of the analysis shows that learning orientation has significant effect on innovative performance in improving the Marketing personnel performance by strengthening internal audit supervision. These empirical findings indicate that learning orientation has a significant effect on innovative performance; learning orientation has a significant effect on the Marketing personnel performance; innovative performance has a significant effect on the Marketing personnel performance; and internal audit supervision can strengthen the effect of innovative performance on the Marketing personnel performance which also have a significant effect on team performance.

Keywords : learning orientation, innovative performance, Marketing personnel performance and internal audit supervision

\section{INTRODUCTION}

This study was based on the different results of previous research, where the results of Froiland et al. (2012), Patterson, (2014) showed that innovative performance has a significant positive effect on Marketing personnel performance, while Nzuve and Bundi (2014) showed that innovative performance has no significant effect on Marketing personnel performance. 
Human resources are important factor in carrying out a business activity. They are those who drive the operation of a business, whether it is a large or a small business. A business will run successfully if supported by qualified human resources in accordance with the needs of the organization. Therefore, an effort by an organization requires a good quality of human resources (Valdez-Juárez et al., 2016).

The quality human resource is needed in the development of an organization to achieve a target set. With good quality human resources, it is not difficult to achieve organizational goal. Human resources need an insight, knowledge, competence and good ability and supported by good morals, honesty and high discipline, if it is owned by human resources, then the development process can be achieved (Patterson, 2014).

An organization in its development process needs to evolve into an organization that achieves the vision and mission. Therefore, an organization needs to be supported with the right human resources that can drive the progress of an organization. The organization needs a commitment from human resources in order to be proud of being part of the organization. With this strong commitment, human resources will work hard for the organizational progress (Valdez-Juárez et al., 2016)

In a banking industry, prime services are needed to provide satisfaction to the users of the services. Therefore, human resources are required to work more focused in fulfilling society's expectation of a good banking service. It requires strong innovation in carrying out responsibilities to improve performance. With high innovation, the Marketing personnel performance will increase (Froiland et al., 2012).

Marketing personnel performance will be achieved if human resources have innovative behavior, which is able to provide new ideas in the work process. High innovative performance will make the work atmosphere fresher. Ferrin, (2016) stated that innovative performance can improve Marketing personnel performance if reinforced with good cultural ethics. However, De Boer (2014) showed that innovative performance can improve Marketing personnel performance if reinforced with good internal audit supervision.

Poh and $\mathrm{Zi}$, (2001) argued that performance is the result achieved by a person whether in quality or quantity in accordance with the responsibilities assigned to him. Besides that, a person's performance is influenced by a level of education, initiative, work experience, and HR Motivation. The work result of human resources is able to support the output produced by an organization, meaning that human resources will have good performance as long as they have high innovation power.

Innovative performance is the ability of human resources in achieving the work by doing something new in accordance with the goals to be achieved. Conceptually, innovative performance can be defined as the degree to which Marketing personnel actually do behavior innovation. Innovative performance can also be understood as behavior where the marketing personnel voluntarily provides access to others regarding innovation and experience. Innovative performance is able to improve human resources performance and the effect will even be stronger when human resources have high human capital (Martina et al., 2008).

Learning orientation is marketing personnel orientation-related to the mastery of knowledge and marketing power skill which is measured by the number or level of interest 
to find a solution of problems through the learning process. Therefore, the higher the learning orientation, the higher the interest for resolving the problem through the learning process. Human resources which have a good learning orientation will be able to complete responsibilities more precisely and quickly in accordance with the expectations of the organization.

An organization is not separated from internal audit or controlling supervision. Internal audit supervision is done to ensure that human resources work in accordance with the expectations of the organization. A good internal audit will support the improvement of Marketing personnel performance through a good HR professional competence. Internal audit supervision is able to moderate the effect of innovative performance on Marketing personnel performance (Ardansyah and Wasilawati, 2014).

Marketing personnel Management is often seen as part of marketing management which is crucial enough to support the success of the company. The Marketing personnel performance contributes greatly to a company. Companies can be remembered by customers because of the performance of its marketing personnel. The tight competition between companies in the global economic era requires the company to always be a leading and best in providing satisfactory service to customers. Competition is an integral part of the company, because the competition is precisely one of the important elements in preparing the right marketing strategy which can provide a positive profit for the company in increasing sales volume and market share in order to win the market competition. One company strategy that can be used as one way to support the success of the company is good human resources. In this case the marketing personnel is one of the human resources of a company that has enough role in achieving company goals.

Marketing personnel is one factor that has an important role in supporting the success of the company because it is a party that has a direct relationship with customers in influencing purchasing decision. To have a quality marketing personnel, unfortunately, the management of a company still pay little attention on marketing personnel. The company sale basically has a life cycle where at one-time sales will experience a decline that may be caused by sales strategy that is no longer in accordance with market conditions. These circumstances encourage companies to implement new strategies in corporate sales management. For that reason, it is required a marketing personnel who have high performance in achieving company success.

Valdez-Juárez et al., (2016) showed that employees who work with high innovative power will be able to complete the job quickly and appropriately and it is able to improve performance. The results of study by Froiland et al. (2012), Patterson, (2014) and ValdezJuárez et al. (2016) showed that innovative performance improves the Marketing personnel performance. Valdez-Juárez et al. (2016) suggests that employees who have a strong orientation to add insight, knowledge and competence indicate a desire to develop through proper learning and this will make employees work with high innovative power. Valdez-Juárez et al., (2016) indicates an increasing orientation of learning is able to improve innovative performance.

Valdez-Juárez et al., (2016) suggested that employees with a strong orientation to add insight, knowledge and competence indicate a desire to develop through proper learning and this can improve their performance. Valdez-Juárez et al., (2016) showed that the increasing of learning orientation can improve HR performance. 


\section{LITERATURE REVIEW \\ Marketing personnel Performance}

Marketing personnel performance is a result achieved by workers in their work according to certain criteria in a particular job. Robbins (2006) stated that Marketing personnel performance is a function of the interaction between ability and motivation. Mas'ud (2004) stated that the purpose of setting performance objectives is to set useful targets not only for performance evaluation at the end of the period but also to manage the work process during the period.

Manzoor et al (2011) stated that Marketing personnel performance is one's success in the doing a job. Performance essentially a work result of employees for certain period. Success or Failure of human performance is affected by performance levels of employees individually or in group. According to Tarricone and Luca (2015), there are 6 criteria used for measure the extent of Marketing personnel performance individually, namely: quality, quantity, timeliness, effectiveness, independence, and work commitment.

\section{Innovative Performance}

Innovative performance is a process whereby individuals are able to work with a strong innovation power by communicating one's intellectual capital to another (Xiangyin and Zheng, 2014 ). Dorner (2012) proposed another definition that innovative performance is all individual behavior directed towards generating, introducing, and applying new things, which are useful in various organizational levels.

Innovative performance is the process where the individuals can afford work with strong innovation power by communicating intellectual capital owned by someone to others. Conceptually, innovative behavior can be defined as level on how far someone actually does behavior innovation. Innovative behavior can also be understood as behavior where a person voluntarily provide access to others about innovation and experience. The indicators of Innovative performance are as follows: (Gallic, 2007)

1. New Idea

2. New way

3. New technique

Companies need to make innovative performance improvements by often holding training for employees both soft skills and hard skills. By Frequent training, the company will help employees to be more trained and accustomed in issuing idea that they have and be able to fight for new ideas that are planned and made for increased employee performance (Putri and Budiastuti, 2014).

Valdez-Juárez et al., (2016) showed that employees who work with high innovative power will be able to complete the job quickly and precisely. As a result, it is able to improve performance. The results of Froiland et al. (2012), Patterson, w (2014) and ValdezJuárez et al. (2016) showed that innovative performance improves Marketing personnel performance. Therefore, the proposed hypothesis is:

\section{H1: The higher the innovative performance is, the better the Marketing personnel performance will be.}




\section{LEARNING ORIENTATION}

Learning orientation shows organizational capability on assumptions in the marketplace of a company that focuses on environmental events / changes which will affect the company's ability to provide satisfaction to customers. The difference between the two concepts of learning orientation is not only based on market knowledge but also give satisfaction to the customer. Learning orientation can facilitate a company to make external changes effectively, such as customer choice of products and technology. The development of corporate capabilities will include organizations to absorb and incorporate new ideas.

Indicators of learning orientation are:

1. Training soft skills

2. Brainstorming

3. job description Mastery.

Learning orientation is the orientation of a person working in an agency, office or so on in improving the competence. Many companies, in the recruitment of human resources, select those who have a high learning orientation because one's learning orientation is considered as one of the quality of human resources, so that human resources with a strong learning orientation can stimulate human resources to work innovatively.

Valdez-Juárez et al. (2016) suggests that employees who have a strong orientation to add insight, knowledge and competence indicate a desire to develop through proper learning and this will make employees work with high innovative power. Valdez-Juárez et al., (2016) indicates an increasing orientation of learning which is able to improve innovative performance. Patterson, (2014) indicated that improvement in learning orientation can encourage innovative performance improvement.

\section{H2: The higher the learning orientation is, The better the Marketing personnel performance.}

Learning orientation is the orientation of human resources related to the mastery of knowledge and skills of a person which can be measured by the number of training followed. So, the more the person works, the more experience he will get. With a lot of orientation to learn, it will make the human resources master the work better. As a result, he will finish the job well and this means the person has a good work effectiveness.

Valdez-Juárez et al. (2016) suggested that employees who have a strong orientation to add insight, knowledge and competence indicate a desire to develop through proper learning and this can improve their performance. Valdez-Juárez et al., (2016) showed that the increasing orientation learning can improve HR performance. The results of this study support the research by Patterson, (2014), which showed that improvement in learning orientation can encourage the improvement of Marketing personnel performance. Therefore, the hypothesis proposed is:

\section{H3: The higher the learning orientation is, the better the Marketing personnel performance will be.}




\section{INTERNAL AUDIT SUPERVISION}

Internal audit / controlling supervision aims to see if all activities undertaken has been in accordance with the plan outlined. Besides that, it is an important thing to determine the upcoming work plan. The principle of effective internal audit help our efforts to organize work planned to ensure that the implementation of such work take place accordingly with a plan.

The functions of internal audit function are as follows:

- Prevent deviations

- Fixing errors or weaknesses, and crack down on abuse and misappropriation.

- Dynamizing organizations and management activities.

- Thickening responsibility.

- Taking Corrective action if implementation deviates from the standard.

In general, internal audit can be done with several steps, including:

- $\quad$ Setting the standard for internal audit supervision.

- Researching, checking, and assessing the results that can be achieved.

- Comparing results with standard.

- Fixing irregularities with corrective action.

Internal controls audits can be done with several methods, among others:

- Comparative : it is the internal audit system done by comparing the results with the plan.

- Inspective: it is a direct inspection system which is useful to figure out the truth about the circumstances of a job execution.

- Verificative: It is an oversight system of examination, usually related to finance and material.

- Investigative: it is internal audit supervision conducted by an investigation.

Internal audit oversight is an activity that compares or measures what is or has been done with the criteria of standard norms or established plans (Sami'an and Aprilian, 2013). Internal audit supervision conducted by supervisors is a thorough internal audit supervision of the implementation of activities by subordinates with the intention of knowing the real activities of every aspect in the implementation of the task or environment of each unit of the organization and not deviate in efforts to achieve the goals and targets set. In any deviation occurs, the director/manager immediately takes necessary remedial measures (Silalahi, 2014). According to Sami'an and Aprilian, (2013) there are two internal audit supervision techniques:

1. Direct internal audit supervision, i.e., the organization's leaders conduct their own internal audits supervision of the activities underway. This internal audit direct supervision can be in the form of direct inspection, on the spot observation and reporting.

2 Indirect Internal audit supervision, internal audit monitoring from distance, this internal audit supervision is done through reports submitted by subordinates. This report can be written and spoken by telephone.

Ardansyah and Wasilawati, (2014) stated that human beings must have limited ability in understanding and executing their work which leads to deliberate and unintentional mistakes. 
To anticipate these errors, a company needs to implement internal audit supervision. Internal audit supervision is "a process to implement what work has been done, its judgment and if necessary correcting with the intention that the implementation of work in accordance with the original plan (Sami'an and Aprilian, 2013)".

Indicators of internal audit supervision are as follows:

1. Auditor supervision on Marketing personnel is done periodically

2. Auditor supervision on Marketing personnel is done transparently

3. Auditor supervision on Marketing personnel is done timely

Ardansyah and Wasilawati (2014) showed that good internal audit of work audits will support the improvement of the Marketing personnel performance through the performance of good innovation from human resources, where internal audit work audits are able to moderate the effect of innovation performance on the Marketing personnel performance. De Boer, (2014) suggested that internal audit supervision can moderate the effect of innovation performance on the Marketing personnel performance. Based on the above, it can be formulated hypothesis 5 as follows:

\section{H4: Internal audit control moderates the effect of innovation performance on Marketing personnel performance}

Based on the explanation, conceptual framework related to the research on the effect of Innovative Performance on improving Marketing personnel Performance (HR) at PT. BPR Nusamba Cepiring can be described as follows:

H3

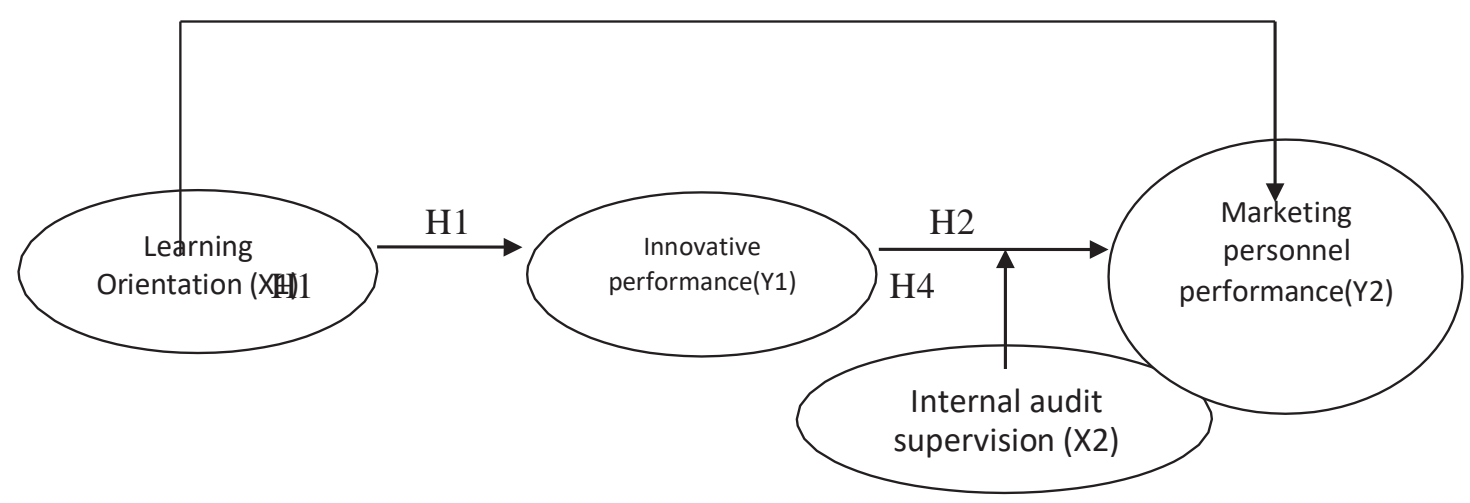

Figure 1.1

Theoretical Framework

\section{RESEARCH METHODOLOGY}

This study was conducted to test hypotheses with the intention of correcting or strengthening the hypothesis in the hope that, in the end, it can strengthen the theory which is used as a foothold.

In relation to the subject, the type of research used is explanatory research, which means that this research emphasizes on the correlation among variables by testing on the description of variables (Singarimbun, 1989). 
Respondents in this study is all the marketing personnel who work in PT. BPR Nusamba Cepiring. This study uses purposive sampling, with criteria of employees who have 1-2 years working experience. Based on purposive sampling, it was obtained a sample of 101 respondents.

Data analysis technique used was path analysis model. Path analysis is an extension of multiple linear regression analysis to estimate the causality relationship between the predetermined variables based on theory. The analysis is used with the help of the SPSS statistical application program. Before analyzing the data, the validity and reliability test of the list of questions / statements submitted were done. After that, The regression analysis with path analysis model was conducted.

\section{DISCUSSION}

To test hypothesis by using t-test, regression analysis is required. Linear regression analysis used in this study with the aim to know whether there is effect of independent variables (Imam Ghozali, 2001). The statistical calculations in the linear regression analysis used in this study is by using SPSS for Windows 11.0. The summary of data processing using SPSS program for $\mathrm{t}$ test is as follows:

\section{Table 1.1}

Test t

\begin{tabular}{clllccc}
\hline No & Dependent variable & Variable Free & B & t count & Sign & Information \\
\hline 1 & Innovative Performance & $\begin{array}{l}\text { Learning } \\
\text { Orientation }\end{array}$ & 0.366 & 3.918 & 0.000 & H1 Received ** \\
2 & $\begin{array}{l}\text { Marketing personnel } \\
\text { performance }\end{array}$ & $\begin{array}{l}\text { Innovative } \\
\text { Performance }\end{array}$ & 0.236 & 2.142 & 0.041 & H2 Received ** \\
3 & $\begin{array}{l}\text { Marketing personnel } \\
\text { performance }\end{array}$ & $\begin{array}{l}\text { Learning } \\
\text { Orientation }\end{array}$ & 0.279 & 3.408 & 0.001 & H3 Received * \\
4 & $\begin{array}{l}\text { Marketing personnel } \\
\text { performance }\end{array}$ & $\begin{array}{l}\text { Moderation of } \\
\text { Internal Audit } \\
\text { Monitoring }\end{array}$ & 0.572 & 2,489 & 0.014 & H4 Received * \\
\hline
\end{tabular}

Source: Regression results, 2017

Description: * Significant at level $1 \%$ ** significant at level $5 \%$

Hypothesis 1 is supported, whereas if the level of learning orientation is higher, then the innovative performance will be higher. When an employee has high learning orientation, then the innovative performance increase. The positive direction of regression coefficient indicates a positive effect of learning orientation on innovative performance. This indicates that employees who have a good learning orientation have a more innovative performance. Patterson, (2014) stated that an improvement in learning orientation can encourage innovative performance improvement.

Hypothesis 2 is supported, where if the innovative performance is higher, then the marketing performance will be higher, when employees have innovative performance, then the marketing personnel performance will increase. Innovative performance can improve the 
Marketing personnel performance. The positive direction of regression coefficient indicates a positive effect of innovative performance on the Marketing personnel performance. This indicated that employees with high innovative performance can improve the Marketing personnel performance. The results of Froiland et al. (2012), Patterson, w (2014) and ValdezJuárez et al. (2016) showed that innovative performance improves the Marketing personnel performance.

Hypothesis 3 is supported, wherein if the level of learning orientation is high, then the performancewillbehigher, whenanemployeehas ahigh learning orientation, thentheorientation study will result in improved performance which can improve innovative performance. The direction of the positive regression coefficient indicates a positive effect of learning orientation on the Marketing personnel performance. This indicates that employees who have a good learning orientation have better performance. Patterson, (2014), showed that improvement in learning orientation can encourage the improvement of marketing personnel performance.

Hypothesis 4 is supported, whereby if the innovative performance is higher, then the Marketing personnel performance is higher with the strengthening of internal audit supervision. When employees have a good innovative performance, then the Marketing personnel performance will increase. Innovative performance is able to improve the Marketing personnel performance with reinforced supervision. The positive direction of regression coefficient indicates a positive effect of innovative performance on the Marketing personnel performance with enhanced internal audit supervision. This indicates that employees who have strong innovative performance towards the organization have better performance if supported by good internal audit supervision. De Boer, (2014) suggested that internal audit oversight is able to moderate the effect of innovation performance on the Marketing personnel performance.

\section{CLOSING \\ Conclusion}

The formulation of the problem in this research is how the effect of learning orientation and innovative performance on improving the Marketing personnel performance through moderation of internal audit supervision. Based on the hypotheses that have been developed in this study, then the research problem that has been proposed can be examined through path analysis test which has been conceptualized through this research that the orientation of learning have a good role in improving the Marketing personnel performance mediated by innovative performance.

Based on the significant support of hypothesis testing, it has addressed the research problems which result in 4 performance improvement of marketing personnel as follows:

- First, the steps in an effort to improve the performance of marketing forces is reinforced through learning orientation.

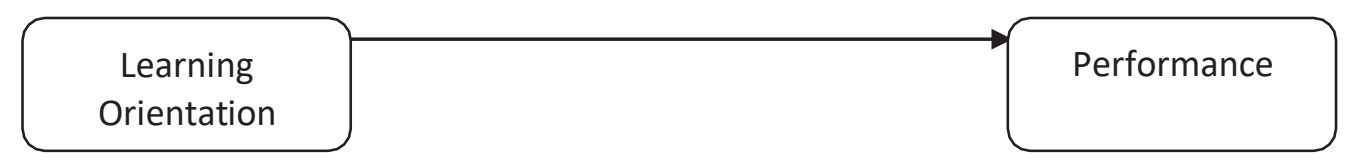


The direction of positive regression coefficient indicates a positive effect of learning orientation on innovative performance. This indicates that employees who have a good learning orientation have a more innovative performance.

- Secondly, in an effort to improve the Marketing personnel performance is reinforced through innovative performance

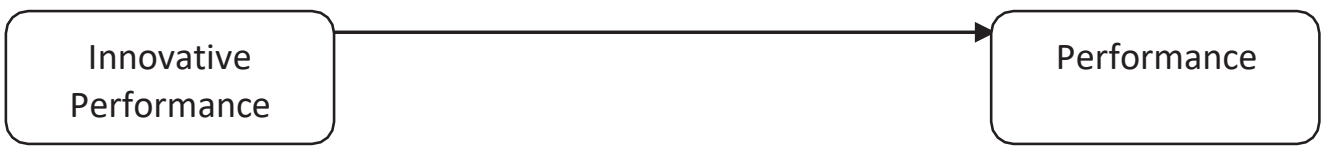

The direction of the positive regression coefficient indicates a positive effect of innovative performance on the Marketing personnel performance. This indicates that employees with high innovative performance can improve the Marketing personnel performance.

- Third, the steps in an effort to improve the performance of marketing forces can be mediated by innovative performance

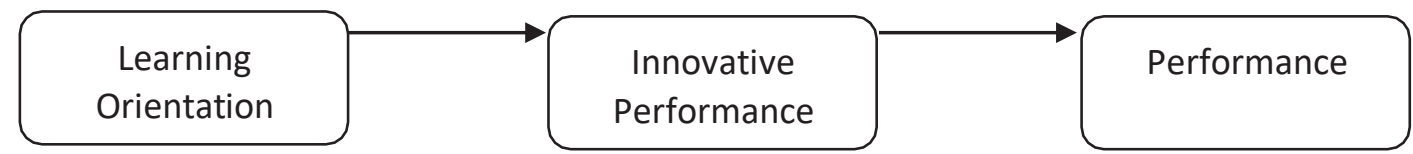

The direction of the positive regression coefficient indicates a positive effect of learning orientation on the Marketing personnel performance. This indicates that employees who have a good learning orientation have better Marketing personnel performance.

- Fourth, the steps in an effort to improve the Marketing personnel performance is moderated by internal audit supervision.

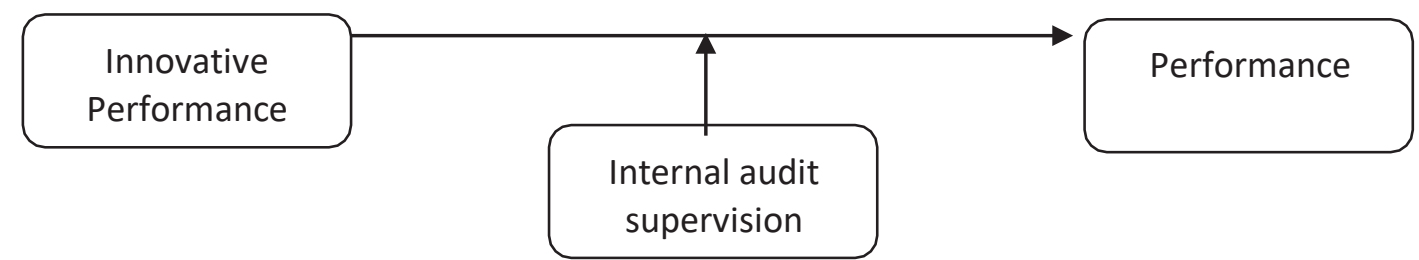

The direction of the positive regression coefficient indicates a positive effect of innovative performance on the Marketing personnel performance with enhanced internal audit supervision. This indicates that employees who have strong innovative performance towards the organization have better Marketing personnel performance supported by good internal audit supervision.

\section{SUGGESTION}

PT. BPR Nusamba Cepiring needs to improve the learning orientation through the appropriate selection and placement, the position of the work needs to be done by the right people through a good selection and proper placement so that the characteristics of manpower is in accordance with work and they can do the job job with full responsibility. Marketing personnel who has already carried out responsibilities by completing the job quickly and on time need to be given self-development. It is expected that the marketing personnel feel more in accordance with the work done and fulfilled the need for his development. Indicators of job description mastery shows the weakest indicator of learning orientation in improving the Marketing personnel performance, it shows that the marketing 
personnel need more emphasis on the mastery of the job desk and the environment in carrying out its work activities in order to improve HR performance. With a strong learning orientation marketing personnel, it will make marketing energy work better.

PT. BPR Nusamba Cepiring needs to improve its innovative performance through periodic training to marketing personnel through soft skill training and brain storming in order to support good competence from PT. BPR Nusamba Cepiring for improving its performance. PT. BPR Nusamba Cepiring also needs to rotate to provide refresher to the marketing personnel in order not to get bored with the work. Indicators of always proposing new ideas showed the weakest value in improving marketing personnel performance. It indicates that the company needs to further stimulate innovation power owned by marketing personnel in order to be able to propose things that are new to improve the performance of human resources. With a marketing personnel with powerful innovative performance, it will make the marketing personnel work better.

\section{REFERENCE}

Ardansyah dan Wasilawati, (2014), "Pengawasan, disiplin kerja dan kinerja SDM," Jurnal Manajemen dan Kewirausahaan

Damayanti, Ni Putu, I wayan Bagja, I Wayan Suwendra, e-Jurnal 2014, Pengaruh Kompetensi Intelektual dan motivasi berprestasi terhadap kinerja SDM PDAM Kab Gianyar

Fadhilah, Ahsan M; dan Ryco F (2014), Peran person job fit dalam rangka peningkatan kinerja, Universitas Udayana

Ghozali, 2011, Aplikasi analisis Multivariate dengan Program SPSS, Badan Penerbit UNDIP, Semarang

Gibson, J.L., Ivancevich, J.M., dan Donnelly, Jr.,J.H., 1989, Organisasi: Perilaku, Struktur, Proses, Penerbit Erlangga, Jakarta.

Gomes, F.C., 1995, Manajemen Sumber Daya Manusia, Penerbit Andi Offset, Yogyakarta.

Indriantoro, Nur, dan Bambang Supomo, 2000, Metodologi Penelitian Bisnis untuk Akuntansi dan Manajemen, BPFE, Yogyakarta.

Iriani, Ida, 2010, motivasi berprestasi, motivasi ekstrinsik dan disiplin kerja pengaruhnya terhadap kinerja SDM pada Dinas Pendidikan Sambas, Jurnal akuntansi Pasca Sarjana Univ Tribuwana Tunggadewi Malang

Langford, D., Hancock, M.R., Fellows, R., dan Gale, A.W., 1995, Human Resources Management in Construction, Longman Scientific \& Technical, London.

Maslow, A.H., 1994, Motivasi dan Kepribadian, Pustaka Binaman Pressindo, Jakarta.

Megan Lee Endres; Steven P Endres; Sanjib K Chowdury; dan Intakhab Alam, (2007), "Tacit knowledge sharing, self efficacy theory and application to the open source community." Journal of Knowledge Management 
Riyanti, Gusti Ayu Riska; dan I Gde Adnyana Sudibya, (2014), "Pengaruh motivasi dan kompetensi terhadap kinerja SDM pada RSU Dharma Usadha," Universitas Udayana

Robbins, Stephen. 2006. Perilaku Organisasi. Prentice Hall. PT Indeks Kelompok Gramedia. Edisi Bahasa Indonesia. Edisi Kesepuluh

Silalahi, Bonar P, (2014), "Pengaruh motivasi, pengawasan dan disiplin kerja terhadap prestasi kerja,” Jurnal Bisnis dan Manajemen Eksekutif

Safwan, Nadirsyah, Syukri Abdillah Jurnal akuntansi Pasca Sarjana Univ Syiah Kuala 2014, Pengaruh Kompetensi dan motivasi berprestasi terhadap kinerja Pengelola Keuangan Daerah Kab Pidie Jaya,

Sami'an dan Estu Aprillian, (2013), "Pengaruh kepemimpinan dan pengawasan terhadap kinerja SDM," Universitas Muhammadiyah Surakarta 